\title{
The past in the past in the mortuary practice of hunter- gatherers: an example from a settlement and cemetery site in northern Latvia
}

\author{
Lars Larsson \\ Institute of Archaeology and Ancient History, Lund University, Lund, SE \\ Lars.Larsson@ark.lu.se
}

\begin{abstract}
During excavations of burials at Zvejnieki in northern Latvia, it transpired that the grave fill included occupation material brought to the grave. It contained tools of a type that could not be contemporaneous with the grave. This is confirmed by the dating of bone tools and other bone finds in the fill. The fill was taken from an older settlement site a short distance away. The fill also included skeletal parts of humans whose graves had been destroyed with the digging of the grave for a double burial. This provides an interesting view of the mortuary practice of hunter-gatherers and an insight into the use of the past in the past.
\end{abstract}

KEY WORDS - hunter-gatherer; mortuary practice; occupation layer; rituals; Mesolithic; Neolithic; Latvia; Northern Europe

\section{Preteklost $v$ preteklosti pri pokopih lovcev in nabiralcev: primer iz naselbine in grobišča $v$ severni Latviji}

\begin{abstract}
IZVLEČEK - Med izkopavanji grobišča Zvejnieki v severni Latviji smo odkrili, da so bili grobovi zapolnjeni z materialom, ki so ga prinesli iz naselbine. Polnilo je vsebovalo orodja, ki niso sočasna z grobovi. To je potrdilo tudi datiranje koščenih orodij in drugih koščenih najdb v polnilu. Le-tega so prinesli iz starejše naselbine, ki se nahaja v bližini. Polnilo je vsebovalo tudi človeške skeletne ostanke starejših grobov, ki so jih uničili pri izkopu za dvojni pokop. Te najdbe nudijo zanimiv pogled na pogrebne običaje pri lovcih in nabiralcih ter nov vpogled $v$ uporabo preteklosti v preteklosti.
\end{abstract}

KLJUČNE BESEDE - lovci in nabiralci; pogrebni običaji; plast poselitve; rituali; mezolitik; neolitik; Latvija; severna Evropa

\section{Introduction}

When the phenomenon 'the past in the past' is discussed, it normally concerns the use of clearly observable monuments such as graves and settlements that were well preserved and easily identified at the time, several centuries after erection, when they become incorporated into a new function (Bradley 2002; Jones 2007). In this case, we have quite another situation, but still a case where there is evidence of how prehistoric people intentionally used remains left by previous generations.
In a society without enduring monuments, earth is the most permanent of materials (Helms 2005). In an archipelagic environment, the distinction between earth and water is clearly established. One lives on earth, and in the occupation layer, the remains of the living society are mixed with soil. Everyday life is buried in the earth, just like the dead members of society. If the same location continues to be settled for a considerable time the remains of the ancestors will still be obvious for several generations. The memory 
of the ancestors will be easy to maintain through a close relationship with their remains. When a pit is dug, the remains of those long deceased will be unearthed, just as when digging a grave, an older grave is exposed. The settlement in itself becomes a monument of the past.

If one and the same area is used as a settlement, a confrontation with the vestiges of past generations cannot be avoided. The relationship with the ancestors will become a frequent issue. A society can either try to avoid this confrontation by moving away (Knutsson 1995) or regard the connection to the ancestors as an important and desirable part of life. If a trust in the connection to the ancestral past exists, then the soil itself will be regarded as an important link between the living and the dead, a link that is directed towards the past and oriented towards the future (Gosdon 1994.15). The use of such soil might be a commemorative practice. The material culture within the soil represents an objectification of the past, yet it is also experienced subjectively (Jones 2007.53).

\section{Excavations at the Zvejnieki settlement and ce- metery complex}

During the period 1964-1977, settlement remains and more than three hundred graves were excavated at Zvejnieki in northern Latvia, under the direction of Francis Zagorskis (2004) (Fig. 1). Altogether, 317 graves were documented. They span the period from the $8^{\text {th }}$ to the $3^{\text {rd }}$ millennium cal $\mathrm{BC}$, and are mostly contemporaneous with the settlement remains in the immediate vicinity (Zagorska 2006) (Fig. 2).

From 2005 to 2009, a new excavation was carried jointly between Latvian and Swedish archaeologists (Larsson 2006; Nilsson Stutz et al. 2008; 2013). The graves were excavated in areas associated with a former farmhouse that had not been available for excavation during previous campaigns (Fig. 2). All the burials were found in the area to the east of the farmhouse. Several were more or less disturbed, as they had been placed in shallow graves and had later been affected by digging. However, two graves turned out to contain interred remains deep enough to be unaffected by later disturbances. The graves were between 0.7 and $0.8 \mathrm{~m}$ deep and contained a very dark fill, typical of graves dated to the $7^{\text {th }}$ and $6^{\text {th }}$ millennium BC. The fill, mixed with soot and charcoal, bore a close resemblance to the occupation layer nearby. In addition, it included a considerable number of flint and bone finds similar to the settlement remains. However, there seemed to be a discrepancy between the date of the burial and some of the artefacts found in the fill.

Buried in one of the graves, No. 313, was a female dated to the mid-7th millennium BC $(7525 \pm 60 \mathrm{BP}$, 6467-6249 cal BC, LuS 8220) (according to Oxcal v.4.1). However, the fill included a fragment of a slotted bone point that should date to the Preboreal or Early Boreal, a phase two millennia earlier (Hartz et al. 2010). In graves excavated previously, discrepancies between the date of the burial and the date of bird as well as fish bones in the fill of the grave have been noted (Zagorska 2006; Mannermaa 2008; Mannermaa et al. 2007).
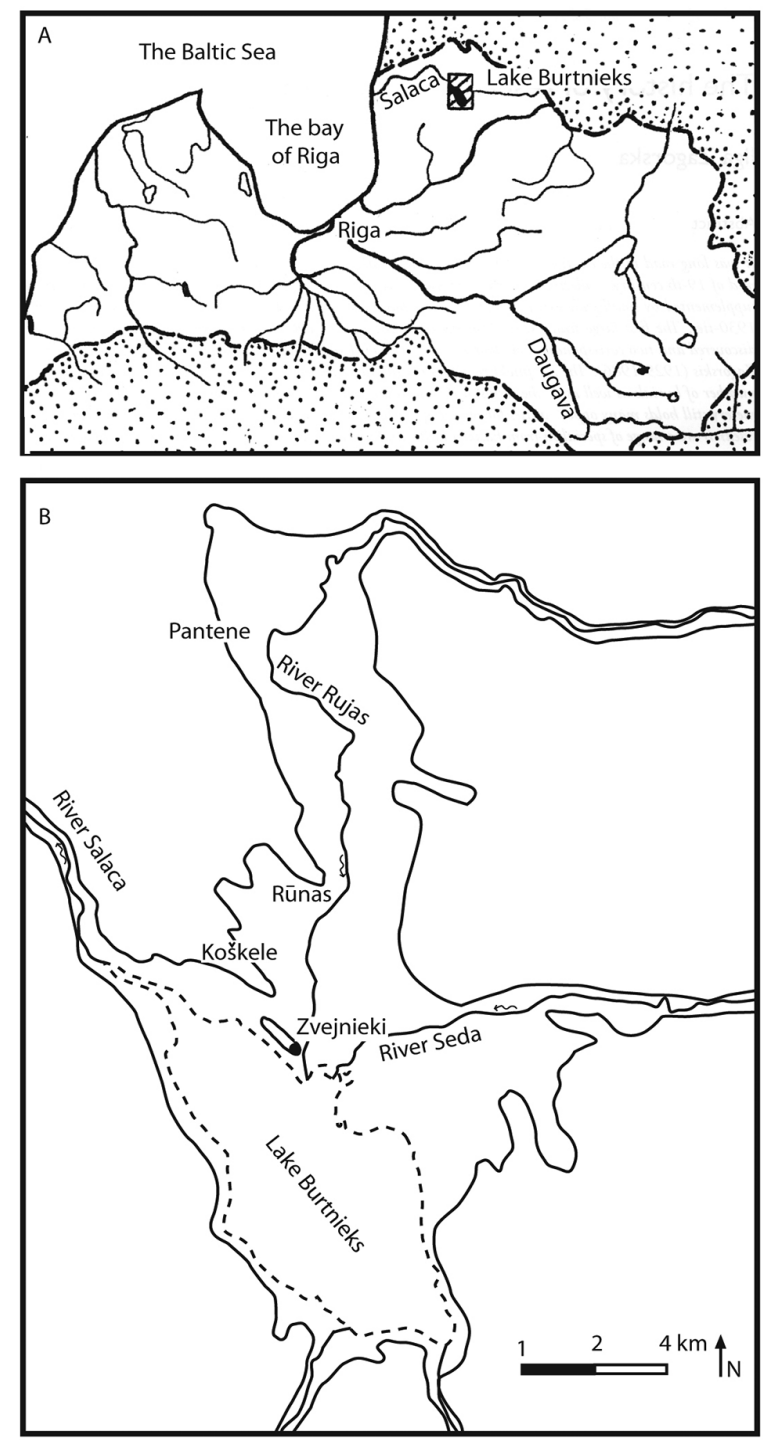

Fig. 1. The location of the Zvejnieki site in Latvia (A) and the location of Lake Burtnieks (B). The solid line marks the extent of the lake when the site was in use, while the extent of the present lake is marked by a dotted line. 
The other deep grave contained a double burial, a male and a female, with a considerable number of grave goods (Larsson 2009) (Fig. 3). Most noticeable are the adornments of the female, with more than 120 amber pendants and two large amber rings, constituting the richest Stone Age amber grave in the Baltic region. This grave covered an area outside as well as inside the former farmhouse, now in ruins.

\section{Black soil}

The house had been rebuilt as late as the 1960s, but sited on the same foundation of stones as a much earlier farmhouse building, probably the first building on the site. As no cellar was dug, this provided a view of how the surface and soil might have looked before the area was farmed, the only opportunity for this kind of investigation within the entire site of Zvejnieki. No settlement remains were identified. However, a number of shallow graves were preserved as little as a couple of decimetres below the previous surface. These graves were even shallower than any previously excavated graves. This reinforced the interpretation that no farming had taken place in the area below the farmhouse during modern times. The fill, with a large number of artefacts (Fig. 4), could therefore not be regarded as soil from an existing occupation layer that the graves had cut through. However, finds from the fill, such as a couple of fragmented leister points of the Kunda type (Fig. 5), indicated that the fill held material that might be older than the graves.

The two interred in Burial 316-317 gave close ${ }^{14} \mathrm{C}$ values. Burial 316 was dated to $5285 \pm 55 \mathrm{BP}, 4256-$ 3979 cal BC (LuS 8217), and Burial 317 to $5105 \pm 50 \mathrm{BP}, 3991-$ 3781 cal BC (LuS 8216) (Fig. 6). Samples were also taken from a bone dagger made of a red dear ulna found close to the right arm of the male in the double grave. The main reason for taking this sample was to obtain a date from a terrestrial species of the same age as the humans in order to learn whether there was a freshwater reservoir effect, because a considerable intake of freshwater fish could have altered the apparent age of the humans (Eriksson 2003; Meadows et al. 2015). The dagger was dated to $4865 \pm 60 \mathrm{BP}$, 3786-3521 cal BC (LuS 7852).
However, the difference is rather small, and it seems that the reservoir effect was of no major importance in this case.

In order to obtain information about the age of the fill, a number of bones with and without traces of alteration were dated. The tip of a Kunda leister head was dated to $8275 \pm 55 \mathrm{BP}, 7486-7090 \mathrm{cal} \mathrm{BC}$ (LuS 8738 ), a beaver vertebra was dated to $6320 \pm 60 \mathrm{BP}$, 5472-5081 cal BC (LuS 8222), a vertebra of wels yielded a date of $6630 \pm 55 \mathrm{BP}, 5636-5482 \mathrm{cal} \mathrm{BC}$ (LuS 8223) and a wild boar incisor was dated to $5455 \pm 50 \mathrm{BP}, 4447-4174 \mathrm{cal}$ BC (LuS 8835). All the dates of bones in the fill are older or considerably older than the skeletons (Fig. 6).

This is an important indication that the fill was not simply taken from the occupation layer, but that soil from a settlement area abandoned a long time before was chosen as fill. This must have been a deliberate choice.

However, comparison with the settlement remains as regards radiometric dates cannot be accomplished, as only three radiocarbon dates are associated with the remains from the settlement, but from the settlement Zvejnieki II, and two later than the actual graves. However, burial 305, dated to $8270 \pm 70$ BP, 7491-7111 cal BC, Ua-3634, held a leister of the Kunda type as the only grave gift and was found dug through an occupation layer, with similar artefacts surrounding the grave. Therefore, the oldest occupation layer is older than the grave. Other Latvian settlements with similar content are dated to the same phase (Zagorska 2006).

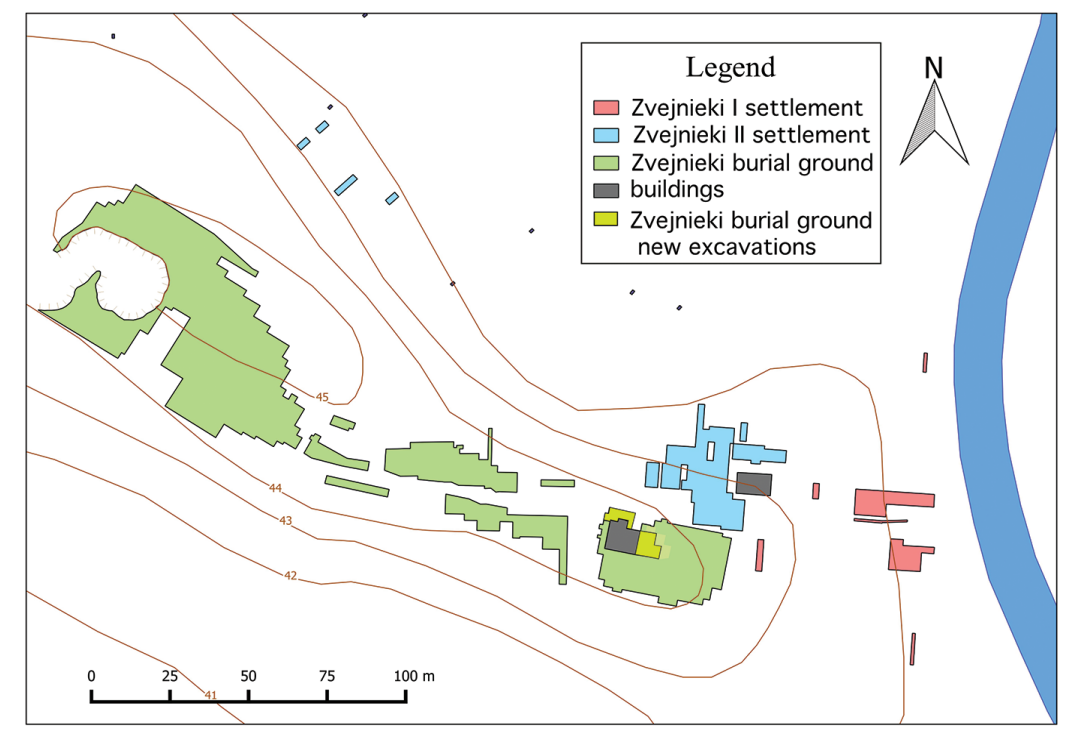

Fig. 2. The Zvejnieki site with the location of the burial ground, the settlements, the farmhouse on the site and the gravel pit. 


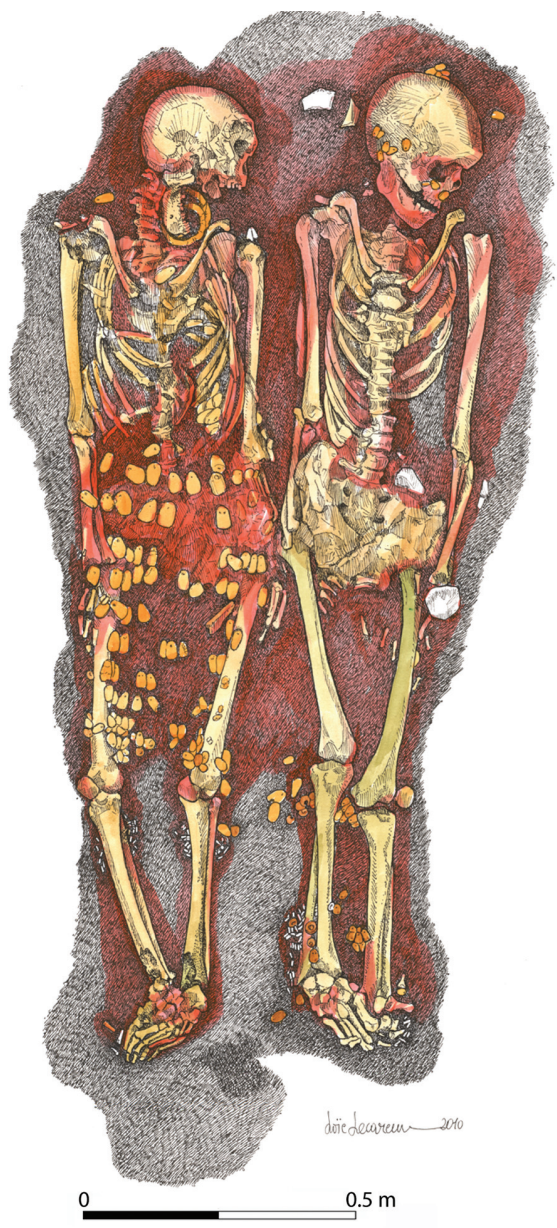

Fig. 3. Double Burial 316-317 (drawing by Loï Lecareux)

According to the dates, which differ by as much as three thousand years, the soil must have been taken from different parts of the settlement area or a location that had been occupied during a considerable time. The dates do not seem to indicate that soil was taken from a contemporaneous settlement. We have to consider that little effort would have been required to bring soil from the occupation, as the settlement is located nearby. Considering the position of the settlement area and the relocation of the settlement during the millennia, it can be estimated that the soil had to be carried for a distance of between twenty and a hundred metres (Fig. 2).

Previously obtained radiocarbon dates for bone finds have turned out to be considerably earlier, as well as somewhat later, than the burial (Zagorska 2006; Mannermaa 2008; Mannermaa et al. 2007). In graves from the $7^{\text {th }}$ millennium (Burial 170), the $6^{\text {th }}$ millennium (Burial 154) as well as the $5^{\text {th }}$ millennium (Burial 164), the bird bones were between three and five millennia older than the burial remains (Mannermaa et al. 2007.Fig. 8). A bone in Burial
165 , dated to the $5^{\text {th }}$ millennia, was just a few centuries older than the grave. These early bird bones are found in graves on the highest part of the gravel ridge and are of about the same age. They have been interpreted as having a natural depositional history, as there are no finds of that age in the settlement. According to a radiocarbon date $9415 \pm 80 \mathrm{BP}, 9123-$ $8921 \mathrm{cal} \mathrm{BC}$ (Ua-18201), as well as on the basis of artefact types, the settlement seems to start during the $9^{\text {th }}$ millennium $\mathrm{BC}$. However, only parts of the settlement area have been excavated, so even the early bones might originate from an occupation layer. Those cases where the bones are younger than the burial provide proof of later disturbance to the graves.

\section{Soil from the settlement}

By removing soil from a settlement used in the distant past and using it in the fill of graves a connection between the present and past was established. There was evidently a need to connect the past with the present, as several other graves are filled with black soil (Zagorski 2004). This practice seems to be most common during the $5^{\text {th }}$ and $6^{\text {th }}$ millennia, but is already represented in the earliest burials in the cemetery. However, not all graves have a black fill, especially the ones older than the $6^{\text {th }}$ millennium $\mathrm{BC}$, so it was a custom more common in the later part of the period of use of the area as a burial site. It might be just a small number of persons within the community who were given this special favour during an early part of the period when the site was used as a cemetery. Some of the graves with the largest numbers of grave goods or with elaborate dress decoration are among those with a dark fill.

That not all graves include black soil in the fill is evident from a grave found not more than a couple of metres from the double grave. Burial 325 consisted of an adult and a child, of which the former was dated to $5230 \pm 50 \mathrm{BP}, 4230-3961 \mathrm{cal} \mathrm{BC}$ (LuS 8833), almost contemporaneous with the double grave. Burial 325 was dug transversely into an older grave. Not a single artefact was found in the fill of this shallow grave. However, higher frequencies of the graves from the $6^{\text {th }}$ and $5^{\text {th }}$ millennium $\mathrm{BC}$ have a fill of black soil. An interesting change in the use of the cemetery might be related to the practice of filling with black soil. The majority of the earliest graves were found in the western, and highest, part of the gravel ridge. During the latter part of the Atlantic, the burials are located on the eastern slope of the ridge, and the eastern part of the ridge starts 
to be the main focus for burials, almost all of which have grave fills of black soil. It seems that the inhabitants ceased burying their dead in the western area, where the ancestors had been buried, but the practice of including the soil of the ancestors' settlement was intensified.

\section{Graves into graves}

Another perspective related to the past in the past concerns the act of burial. In addition to tools and bones from wild animals, some more or less disarticulated human bones were found in the fill of the double grave (Fig. 6). The difference between the dates $6050 \pm 55$ BP, 5206-4794 cal BC (LuS 8218) and $5830 \pm 60 \mathrm{BP}, 4835-4541 \mathrm{cal} \mathrm{BC}$ (LuS 8219) indicates that the human bones in the fill originate from at least two different individuals, several hundred years older than the two burials in the grave. That graves were dug into older graves, partly destroying them, is apparent from the documentation of the excavations in the 1960s and 1970s (Zagorski 2004).

This habit became particularly obvious when the area below the farmhouse was opened up during the most recent excavation season. Several of the exposed graves had been partly destroyed by the digging of later graves. At least two graves had been affected by the digging of the double grave; it was possible to trace a finger bone from the fill to an adjacent grave (Burial 318).

It does not seem to have been of any special concern if an older grave was found in the course of digging a grave; digging continued anyway. No special practices were brought into action if an older grave was found. Skeletal parts that were found close to the edge of the grave might be pushed into the wall, as in the grave for the double burial. However, those found in the more central part of the grave were collected and later included in the fill.

We do not know how many people were buried at Zvejnieki. A total of 317 graves were recorded in the 1960s and 1970s, including some mass burials with as many as six individuals (Zagorski 2004; Zagorska 2006). We know that a number of graves had already been destroyed in the western part of the cemetery during the initial digging for gravel. Based on that knowledge, a calculation of about four hundred graves is most realistic. Already in the mid$19^{\text {th }}$ century the site was well known for skeletal parts being brought to the surface by ploughing. That a considerable number of burials had been placed in shallow graves was well recorded during the excavation below the floor of the farmhouse. If ploughing had been carried out at the same depth as outside the house, then most of the documented graves would have been destroyed. This means that a considerable number of graves were lost during the farming of the fields around the farm. The most plausible number of graves originally located in the cemetery could be six hundred or even more. However, we have to consider the long duration of the cemetery. Even with as many as six hundred graves, the number of graves per generation corresponds to a small group of people, assuming that all were buried in the cemetery. The high number of interred children is an indication that most of the inhabitants were actually buried on the site (Zarina 2006).

It would seem strange if the people digging the grave were not aware that they might hit old graves. We do not know if any grave markers were used. No stone covering has been documented and no colouring from posts has been noticed. One indication that some graves were marked is evident from the double grave. In the uppermost part of the fill, an elongated stone, $0.3 \mathrm{~m}$ in length, was found in an upright

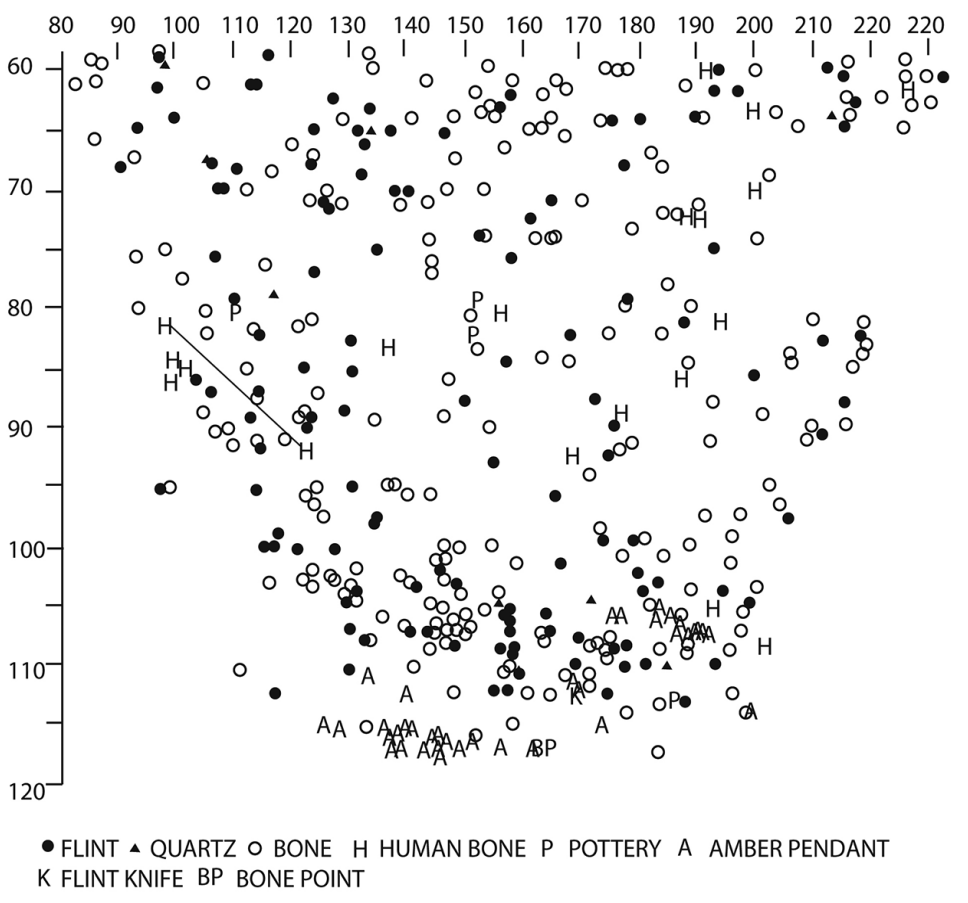

Fig. 4. The fill of the double Burial 316-317 in a 20-cm-thick transverse section. 


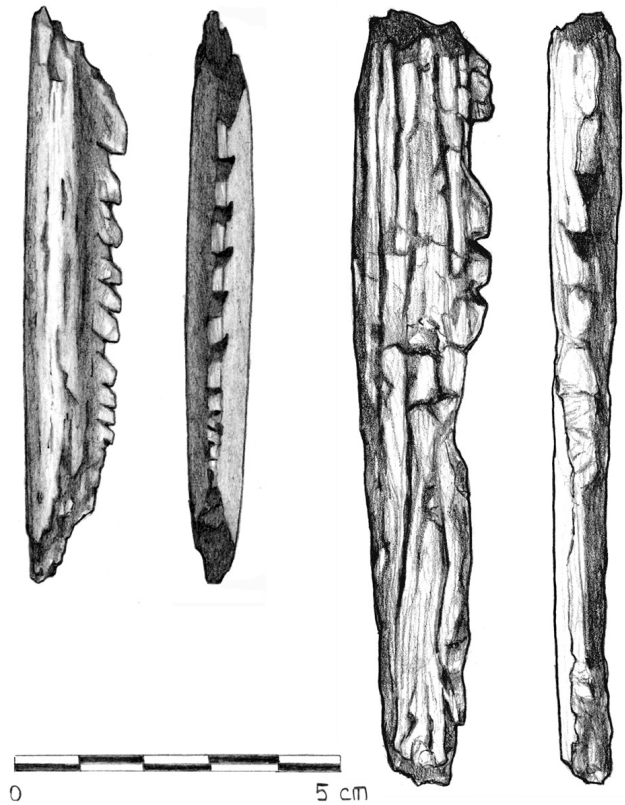

Fig. 5. Fragments of leister points of the Kunda type found in the fill of the double Burial 316-317 (drawings by Loic Lecareux)

position. This stone might have been visible after the grave was refilled. On the other hand, the stone would have been ploughed away if the grave had been located outside the protected area of the farmhouse. This means that ploughing may have removed stones that marked graves.

Regardless of whether any grave markers existed, it did not bother the diggers if they hit an older grave; they cut through it. It might even be possible that digging a new grave into an older one had the same meaning as the fill: the new burial became linked to the earlier inhabitants of the site.

Like the soil of the ancestral occupation layer, the soil of the cemetery was mixed not only with the remains of everyday life, but also with the ancestors themselves. The skeletons were the durable substances associated with a cosmological sense of history (Helms 1995). However, the double grave was never affected by later grave-digging, perhaps due to the marking of the grave, which saved it from destruction. It could be that black soil - ancestral soil in this area, which was reserved for the dead, might have had a special meaning that made further digging inappropriate. Furthermore, most graves with an occupation layer fill are deeper than the majority of graves within the cemetery.

Several graves in the cemetery at Zvejnieki include more than one individual. As many as six individuals were buried in one grave. Occasionally, a disease or accident might have taken a number of lives. In most cases, natural death was not often the cause of death of those interred at Zvejnieki. In several cases, the black soil seems to have been used as a marker for the deposition of further graves when individuals who died somewhat later were added to a grave. In these cases, the inhabitants still had a good memory of the first buried individual, who could have functioned as a guardian for deceased relatives. To place a recently deceased person close to an individual buried previously could have been considered a desirable action.

We have to be aware that the use of the settlement as well as the cemetery continued for several millennia, during which mortuary practices might have changed considerably with respect to the view of past inhabitants. However, during most of the time, a relationship between the dead and the living was established that brought the living into close connection with the ancestral remains, the remains of everyday life in old occupation layers as well as the remains of the inhabitants themselves.

\section{Grave fills of occupation layer in other hunter- gatherer societies}

Concerning the graves at Zvejnieki from the $6^{\text {th }}$ and $5^{\text {th }}$ millennium, there seems to have been a tradition of using the fill as a marker of the connection between the past and present. Does something similar exist at other contemporaneous graves or cemeteries? One site to look into in more detail is Skateholm in southern Sweden, with more than eighty graves in three cemeteries dated to the Late Mesolithic (Larsson 1993). It was apparent in some graves that the fill had been arranged in sections of different colours. This was connected with a considerable variation in the character of artefacts in the fill (Larsson 2016). The graves with a high number of artefacts were also the darkest in colour. At the time of excavation, it was considered that soil from an existing occupation had penetrated during the digging of the grave. But in certain cases, the marked difference between different fills of the same grave indicates that soil from occupations was used intentionally. In one of the graves, the area closest to the wall of the grave consisted of light sand, with no artefacts, while the fill of the central part of the grave was dark, with a high number of artefacts. The preservation at Skateholm cannot be compared to the situation in Zvejnieki. Bones were found among the artefacts in the fill, but an insufficient organic component to be used for dating. However, based on 


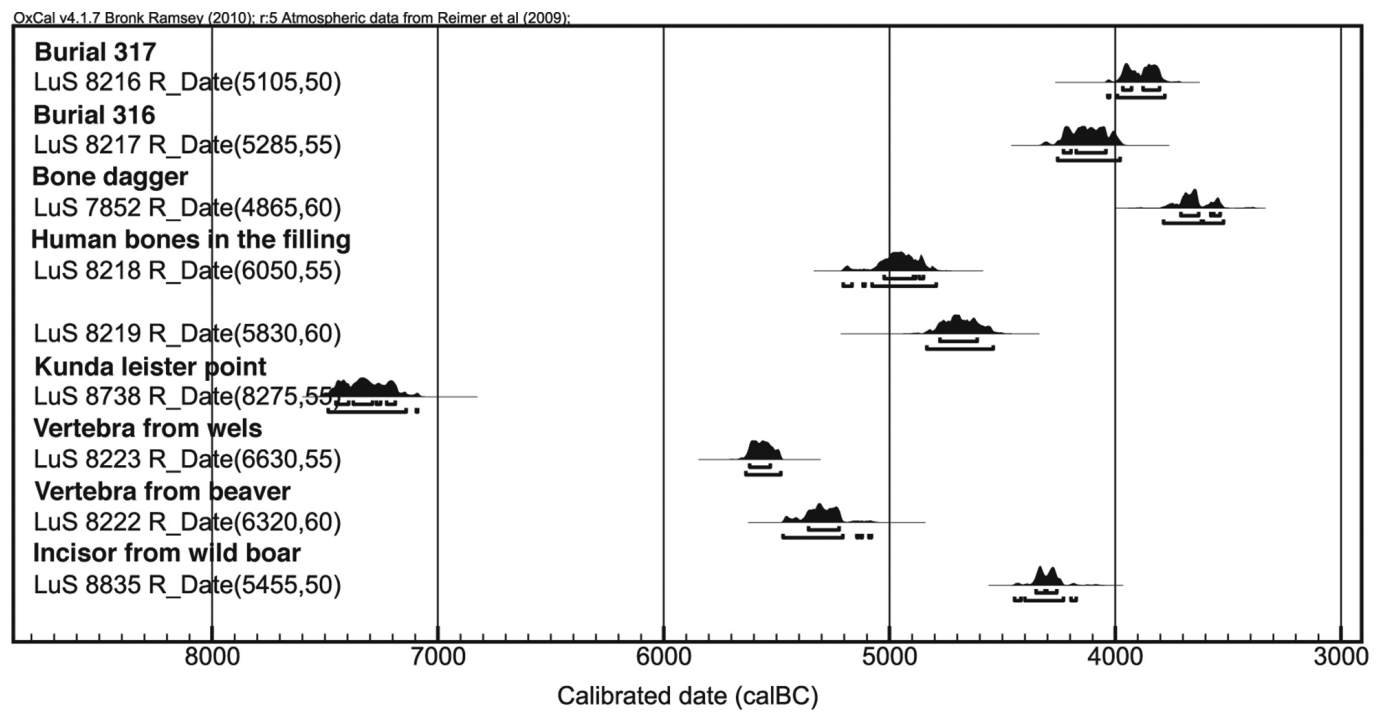

Fig. 6. The dates of the burials, a bone dagger provided with the burial, the finds in the fill and human bones in the fill.

some finds, there is a strong indication that earth was taken from another site and used as fill. Somewhat older sites from which soil could have been taken to be used as fill are known in the immediate neighbourhood, such as Skateholm II on a small island close to Skateholm I, and sites along the shoreline of the former lagoon.

\section{Handling soil from old occupation layers}

In a general sense, the secondary use of occupation material might cause severe problems with the dating of layers and features. One example can serve to illustrate the problem. In the excavation of bog sites in the bog Rönneholms mosse in central Scania, the southernmost part of Sweden, several stages of settlement have been documented (Larsson, Sjöström 2010). During a recent excavation of the site Rönneholm 10, two layers were identified that belong to the Kongemose Culture of the Middle Mesolithic. However, the uppermost layer also included artefacts from the older Maglemose Culture. However, the microliths from the older part of the Mesolithic were all found in a sandy layer below a hearth (Sjöström 2011). The sandy layer was created in order to prevent the fire from burning into the peat below. As the surrounding area consists only of peat and gyttja layers, the sand must have been trans- ported to the bog site from the firm shore. By accident or consciously, sand from an older settlement was brought in a vessel into the lake and laid down as a layer on which to build the fire.

The admixture of older occupation layer in a grave fill might make the use of charcoal, for example, as a sample for radiocarbon dating of the grave highly unreliable. The fill might be of a much earlier date than the burial. But when collagen is lacking in the bones of the burial, there are no other possibilities. A date based on the fill should then be regarded as a terminus post quem. Dating a grave from the tools found in the fill involves similar source critical problems that require very careful consideration.

The use of occupation soil might also have some consequences in the form of the alteration of stratigraphy. A grave such as some of those at Zvejnieki holds about one cubic metre of soil. It seems that soil was taken from different parts of the settlement. However, with several tens of graves, the disturbances to the original layers could have been considerable. When excavating occupation layers, such soil removals might be taken as evidence of much later interference. If not identified, the disturbances might cause severe problems concerning the interpretation of the stratigraphy. 


\section{References}

Bradley R. 2002. The Past in Prehistoric Societies. Routledge. London.

Eriksson G. 2003. Norm and Difference. Stone Age dietary practice in the Baltic region. Theses and papers in Scientific Archaeology 5. Stockholm University. Stockholm.

Gosdon C. 1994. Social being and time. Blackwell. Oxford.

Hartz S., Terberger T. and Zhilin M. 2010. New AMS-dates for the Upper Volga Mesolithic and the origin of microblade technology in Europe. Quartär 57: 155-169.

Helms M. 2005. Tangible materiality and cosmological others in the development of sedentism. In E. DeMarrais, C. Gordon and C. Renfrew (eds.), Rethinking materiality: The engagement of mind. McDonald Institute Monographs. Cambridge: 117-130.

Jones A. 2007. Memory and Material Culture. Cambridge University Press. Cambridge.

Knutsson H. 1995. Slutvandrat? Aspekter på övergången från rörlig till bofast tillvaro. Aun 20. Uppsala.

Larsson L. 1993. The Skateholm Project: Late Mesolithic Coastal Settlement in Southern Sweden. In P. Bogucki (ed.), Case Studies in European Prehistory. CRC Press. Ann Arbor: 31-62.

2006. Research at Zvejnieki, northern Latvia. A preliminary report. Mesolithic Miscellany 18(1): 15-16. www. york.ac.uk/depts/arch/Mesolithic/index.htm

2009. Zvejnieki - past, present and future. A MesolithicNeolithic settlement and cemetery site in northern Latvia. In N. Finlay, S. McCartan, N. Milner and C. Wickham Jones (eds.), From Bann Flakes to Bushmills; papers in honour of Professor Peter Woodman. Prehistoric Society Research Paper 1. Oxford: 124-132.

2010. A Double Grave with Amber and Bone Adornments at Zvejnieki in Northern Latvia. Archaeologia Baltica 13: 80-90.

2016. Some aspects of mortuary practices at the Late Mesolithic cemeteries at Skateholm, southernmost Sweden. In J. Grünberg, B. Gramsch, L. Larsson, J. Orschiedt and H. Meller (eds.), Mesolithic burials - Rites, symbols and social organisation of early postglacial communities. International Conference Halle (Saale), Germany, $18^{\text {th }}-21^{\text {st }}$ September 2013. Tagungen des Landesmuse- ums für Vorgeschichte Halle Band 13/II. Landesamt für Denkmalpflege und Archäologie Sachsen-Anhalt. Halle: 175-184.

Mannermaa K. 2008. Birds and burials at Ajvide (Gotland, Sweden) and Zvejnieki (Latvia) about 8000-3900 BP. Journal of Anthropological Archaeology 27: 201-225.

Mannermaa K., Zagorska I., Jungner H. and Zarina G. 2007. New radiocarbon dates of human and bird bones from Zvejnieki Stone Age burial ground in northern Latvia. Before farming 2007: 2-17.

Meadows J., Bērziņš V., Brinker U., Lübke H., Schmölcke U., Staude A., Zagorska I. and Zarina G. 2015. Dietary freshwater reservoir effects and the radiocarbon ages of prehistoric human bones from Zvejnieki, Latvia. Journal of Archaeological Science: 678-689.

Nilsson Stutz L., Larsson L. and Zagorska I. 2008. More Burials at Zvejnieki. Preliminary results from the 2007 excavation. Mesolithic Miscellany 19(1): 12-16. www.york. ac.uk/depts/ arch/Mesolithic/ index.htm

Nilsson Stutz L., Larsson L. and Zagorska I. 2013. The persistent present of the dead: recent excavations at the hunter-gatherer cemetery of Zvejnieki (Latvia). Antiquity 87 (338): 1016-1029.

Sjöström A. 2011. Mesolitiska lämningar $i$ Rönneholms mosse. Arkeologisk förundersökning 2010. Hassle 32:18, Stehag socken, Eslövs kommun, Skåne. Rapporter från Institutionen för arkeologi och antikens historia Nr. 4. Lunds universitet. Lund.

Zagorska I. 2006. Radiocarbon chronology of the Zvejnieki burials. In L. Larsson, I. Zagorska (eds.), Back to the origin. New research in the Mesolithic-Neolithic Zvejnieki cemetery and environment, Northern Latvia. Acta Archaeologica Lundensia Series 8(52). Almqvist and Wiksell International. Stockholm: 91-114.

Zagorskis F. 2004. Zvejnieki (Northern Latvia) Stone Age cemetery. British Archaeological Reports IS 1292. Archaeopress. Oxbow. Oxford.

Zarina G. 2006. Palaeodemography of the Stone Age burials at Zvejnieki. In L. Larsson, I. Zagorska (eds.), Back to the origin. New research in the Mesolithic-Neolithic Zvejnieki cemetery and environment, Northern Latvia. Acta Archaeologica Lundensia Series 8(52). Almqvist and Wiksell International. Stockholm: 133-148.

\section{back to contents}

